\title{
GENETICALLY MODIFIED TREES: PRODUCTION, PROPERTIES, AND POTENTIAL
}

\author{
by Kevan M.A. Gartland'1, Robert M. Crow'1, Trevor M. Fenning'ㄹ, and Jill S. Gartland'1
}

\begin{abstract}
Genetic modification using Agrobacterium- or biolisticmediated gene transfer can overcome the limitations of conventional tree breeding. Alternatives to the use of antibiotic resistance selectable markers and how they might be used to overcome potential public concerns are described. Applications of genetic modifications to trees include altered wood properties, speeding up breeding cycles, forests as pharmaceutical factories, dendroremediation, and improved resistance to pests and diseases, as well as the restoration of sensitive landscapes.
\end{abstract}

Key Words. Genetic modification; trees; forest biotechnology; forestry; genetics.

Trees make up more than $30 \%$ of the land biosphere and play an essential part in our lives by photosynthesizing, cleaning the air, and contributing to the beauty of landscapes as well as being a major source of fuel and processed products. Progress in improving trees using genetic modification (GM) is discussed herein. Technologies for speeding up tree breeding using biolistics and Agrobacteriummediated genetic modifications are described. These technologies lead to applications including modifying wood composition and structure, manipulating growth and development, improving pest or disease resistance, and landscape restoration.

\section{CONVENTIONAL TREE BREEDING}

Traditional approaches to tree improvement have involved the identification of mature trees with desirable phenotypes, followed by their incorporation into breeding programs. The length of time needed for trees to reach reproductive maturity, often in excess of 20 years, before controlled crosses can be made is the limiting factor for tree improvement (MartinTrillo and Martinez-Zapater 2002). Furthermore, there is no guarantee that the desired progeny phenotypes will be identified. The application of biotechnology can overcome many of the drawbacks associated with conventional breeding strategies. This may be achieved using micropropagation or somatic embryogenesis techniques (Dandekar and James 1998) to produce large numbers of phenotypically similar plants, at rates exceeding those attainable in nurseries, or via the use of genetic modification technologies (Trick and Finer 1999) (Table 1).

There is enormous potential for speeding up tree breeding cycles by the use of genetic modification. Systems have been developed for gene transfer, selection of novel gene-containing shoots, and stimulating regeneration for both broadleaved and coniferous trees (Fenning and Gartland 1995; Wenck et al. 1999). The systems use either the soil-based microorganism Agrobacterium or DNA-coated particle bombardment, known as biolistics.

Two species from the genus Agrobacterium (A. tumefaciens and $A$. rhizogenes) have been used for gene transfer into trees (Pena and Seguin 2001). A small section of the bacterial DNA, known as T-DNA, is transferred into and expressed within the plant nuclear genome. Agrobacterium tumefaciens, the causative agent for crown gall disease, is widely used after the functional deletion of the auxin and cytokinin biosynthetic genes from the Ti, or tumor-inducing, plasmid. A separately replicating plasmid, known as a binary vector, can be introduced and used to deliver desired genes into the plant cell, from which phenotypically normal transgenic trees can be regenerated (Gartland and Davey 1995).

Agrobacterium rhizogenes, responsible for hairy root disease, transfers genes from an Ri, or root-inducing, plasmid (Kaneyoshi and Kobayashi 1999). A feature of this disease is the formation of profuse, fluffy white roots at the site of inoculation (Figure 1). This enhanced rooting may be of value for urban trees in helping establishment or in

Table 1. Genetic manipulation technologies.

\begin{tabular}{ll}
\hline Technology & Definition \\
\hline Genetic manipulation & Introduction of new genetic material via laboratory methods. \\
Biolistics & Use of helium-, gunpowder-, or electrical-discharge-mediated \\
& force to propel DNA-coated tungsten or gold microprojectiles \\
& into cells. \\
Agrobacterium tumefaciens & Soilborne bacterium causing crown gall disease of fruit trees. \\
& Used by biotechnologists to transfer any DNA into plant cells, \\
Agrobacterium rhizogenes & from which transgenic plants are regenerated. \\
& Soilborne bacterium causing hairy root disease. Transfers \\
& bipartite piece of bacterial DNA into plant genome, inducing \\
& elevated auxin synthesis and auxin sensitivity characterized \\
& by fluffy white hairy roots. \\
\hline
\end{tabular}




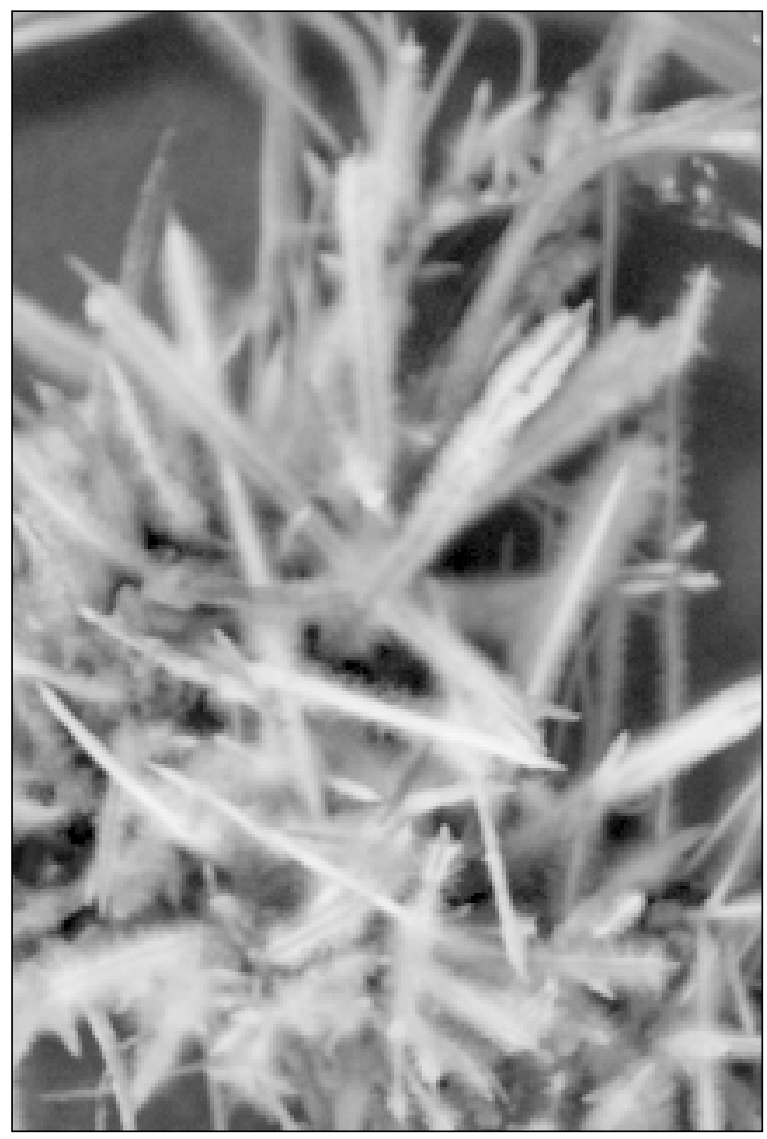

Figure 1. Hairy roots of willow (Salix spp. hybrid).

surviving transplant shock or drought stress (Herschbach and Kopriva 2002). Additionally, the Ri plasmid may be valuable in promoting the rooting of prized scion stocks without the need to graft to a root stock. Trees regenerated from hairy roots are frequently dwarf in stature, often with reduced internode distance and pronounced leaf wrinkling (Gartland and Davey 1995). Such trees may be attractive for streetscape, park, or domestic garden situations and may have occurred spontaneously in some plant species without human interference.

Particle bombardment systems, often known as biolistics, may be used for genetic modification of almost any tree tissue. Typically, DNA-coated $<1 \mu \mathrm{m}$ diameter tungsten or gold microprojectiles are fired at the target tissue; some of the DNA delivered on the projectile is taken up into the cell nucleus and is expressed using the cellular machinery from which whole trees can be regenerated (Ellis et al. 1993). When used with single gene traits, these genetic modification technologies can be used to overcome reproductive, temporal, and geographical isolation barriers to tree improvement. Genetic modification can be combined with other biotechnological tools, such as the analysis of genomic DNA sequences, to increase understanding of tree growth, development, and stress responses (Suarez et al. 2002). Potentially useful genes, such as those for disease or pest resistance, can be introduced into the plant cell nuclear genome by these methods (Adams et al. 2002).

Applying GM technologies to trees requires an ability to select and characterize the genetically modified tissues before regenerating them via shoots into new trees. Expression of a selectable marker gene is used to identify genetically modified cells. The most widely used selectable marker genes include neomycin phosphotransferase II (npt II) encoding resistance to the antibiotics kanamycin and G418, and resistance to herbicides such as glyphosate (Hansen and Wright 1999). Alternative selectable markers based on existing metabolic pathways have recently emerged. Expression of these counterselection markers typically leads to the formation of toxic metabolites in unmodified cells (Daniell and Dingra 2002).

Whichever type of selectable marker is used, a second biochemical reporter gene, which can be detected visually or by a simple assay, is often used. The $\beta$-glucuronidase (gus A) gene, originally isolated from the gut bacterium Escherichia coli, and the green fluorescent protein $(g f p)$ from the jellyfish Aequoria victoria, are the most widely used reporter genes in trees (Jefferson et al. 1987; Main et al. 1998). Neither of these reporter genes convey any selective advantage on the cells expressing them but simply give greater confidence in identifying genetically modified tissues. These tissues can be differentiated to form shoots and then rooted in the presence of the selective agent, using established micropropagation techniques.

Further confirmation of successful genetic modification is obtained using DNA-DNA hybridization and functional testing for the gene of interest. This process can take many months, but, when successfully completed, the plantlets can be transferred to soil following acclimation in, for example, a mist propagation unit. After appropriate risk assessment, regulatory approval for the release of GM trees into the environment may be sought. Most tree genetic modifications have been carried out with Populus hybrids, eucalypts, pine, and spruce (Pena and Seguin 2001).

\section{POTENTIAL PUBLIC CONCERNS BEING ADDRESSED}

The application of GM technologies to trees has raised a number of potential public concerns. Many of these concerns, although not all, are the same as those raised for GM annual crop plants, including the potential for spread of antibiotic or herbicide resistance genes to other nontarget species from GM trees; the potential for long-distance pollen spread over many years from long-lived trees; the potential for adverse effects on biodiversity from forests of GM trees; and any unexpected effects. The latter might include effects such as transferred genes becoming silenced, or gene insertions having unforeseen developmental effects many years after release. 
The potential concern over the spread of antibiotic resistance to other organisms is being addressed at a number of different levels. First, it is necessary to consider whether the antibiotic agent is used extensively for human health or veterinary purposes in the proposed release areas. In the United Kingdom and much of the European Union, for example, very little use is made of kanamycin in clinical or veterinary practice, which reduces the likelihood of damage to human health occurring as a result of using kanamycin to select for genetically modified trees.

At this time, there is no evidence for significant environmental damage at species or ecosystem levels from the use of antibiotic resistance genes. This lack of evidence is despite more than 81 biosafety assessments having been carried out within the European Union alone. A recent review of these GM organism safety projects has concluded, after 70 million Euros (US\$62.5 million) of research by more than 400 multinational research consortia, that GM crops are "probably ... safer than conventional plants and foods" for both the environment and human consumption (Bouchie 2001). Additionally, coordinated studies from U.S. and Canadian scientists have shown that the impact of Bacillus thuringiensis (Bt) corn pollen from current commercial hybrids on monarch butterflies is negligible (Sears et al. 2001). Antibiotic resistance markers have been extensively used in North American food crop trials for at least 15 years (Stewart and Wheaton 2001).

Alternative selectable markers being developed include the isopentenyl transferase gene from the Agrobacterium $\mathrm{Ti}$ plasmid embedded within a transposable element (Ebinuma et al. 1997). An estradiol-induced recombinase protein can excise DNA at specific recognition sites flanking a selectable marker gene (Ow 2001). Genes for detoxifying unusual substrates such as 2-deoxy-glucose-6-phosphate, or genes enabling unusual nutrients to be assimilated, such as phosphomannose isomerase (Hansen and Wright 1999), have also become available.

Recent EU legislation limits the use of antibiotic resistance marker genes where there is evidence of significant potential damage to human health or the environment. Similarly, the potential risks from individual herbicide resistance genes being transferred to other plants must be put into context. Resistance to herbicides, such as RoundUp® or glyphosate, the most commonly quoted in anti-GM literature, can only become a significant problem if we rely on it as a sole source of killing weeds (Strauss et al. 1997). More important, it is often overlooked that use of herbicides in forestry is infrequent due to health concerns and there are distinct advantages in using non-persistent formulations with low ecotoxicity.

It is likely that new and future generations of herbicides, with different modes of action, will be transferred from the annual crops arena to forest trees. This is likely to greatly reduce our reliance on glyphosate, the active ingredient in Round-Up®, as other herbicides become commonplace. Herbicide resistance genes may also provide new alternatives to the use of antibiotic resistance in future GM trees.

The potential for trees to spread pollen over long distances is not disputed. Where GM trees are concerned, scientists cannot yet completely guarantee that pollen formation can be prevented in every individual tree, although exercising flowering control has been suggested both for limiting invasiveness as well as potential for pollen transfer (Adams et al. 2002). Such an expectation, however, misses an important question: What impact would GM pollen grains have if released into the environment? There is currently no clearly compelling evidence of significant damage due to limited amounts of GM tree pollen being able to spread within the environment (Strauss et al. 2001). Plants, including trees, have been exchanging genetic material within and between species on a large scale for millions of years. As yet, this exchange does not appear to have produced large-scale ecological problems.

If transfer of GM tree pollen really is a significant issue, then sterility systems for inducing reproductive incompetence (Mouradov and Teasdale 1999) or trunk grafting (LevYadun and Sederoff 2001) will become more useful in alleviating these concerns and their use encouraged in GM trees (Strauss et al. 1995). Even if a distinct adverse effect of allowing GM trees to flower is found, beyond that of simply promoting genetic exchange, it is likely that any such effects could be ameliorated using short rotation forestry, with limited, or indeed no flowering potential. Once again, any risks introduced from limited GM tree pollen transfer must be placed into context versus the risks from introduced exotic germplasm (Richardson 1998). Additionally, recent evidence suggests that transgenic poplar DNA is unlikely to persist in soils for more than 4 months before being degraded, limiting potential for transfer to soilbased microbes (Hay et al. 2002)

Two other potential concerns expressed about GM trees relate to their longevity and the potential for unexpected effects, once released into the environment. Unexpected effects might include gene silencing, in which expression of an inserted gene ceases. Releasing and monitoring a large number of independently genetically modified trees could overcome this potential problem, because the available evidence suggests the frequency of gene silencing events is rare (Dominguez et al. 2002a). A similar approach is already taken by commercial foresters, who generally wish to avoid monocultures. Additionally, our understanding of genetic stability is increasing as sequences such as matrix attachment regions (MARs), which appear to improve the consistency of gene expression, become more widely used (Allen et al. 2000). The relative longevity of trees is as much a benefit as a potential concern, because their potential economic or amenity value can extend for hundreds of years. 
Many of the publicized potential concerns about GM trees are either misplaced due to a lack of public understanding, or they may be actively managed until such times as further research, including field trials, can resolve these issues. It should not be forgotten that, since 1994, more than 3.5 trillion GM plants have been grown in the United States alone, without any significant ecological or human health consequences being identified (Stewart and Wheaton 2001). These numbers include more than 250 field trials of GM trees, although most of these have been with poplars and eucalypts (Rautner 2001; Gartland et al. 2003).

Our knowledge and understanding of how GM trees function and perform in the wider environment can only be aided by further field trials, using a wider range of trees, as they become available through advances in genetic modification and regeneration technologies.

\section{APPLICATIONS OF GM TECHNOLOGY TO TREES}

Examples of the potential benefits that genetic modification can bring to forestry and arboriculture include improved yields; modifying lignin content; speeding up breeding cycles; the production of valuable pharmaceuticals from trees; cleaning up environmental pollution; more effective management of pests and diseases; and enhanced amenity and landscape restoration value.

Increasing yields from plantation forests by genetic modification will allow more wild forests to be left undisturbed. To this end, findings that at least two species of aspen (Populus tremuloides and P. tremula) grow faster after genetic modifications are most encouraging (Hu et al. 1999; Tzfira et al. 1999) (Figure 2). Among the wood quality traits that can now be altered by genetic modification are the composition and processing properties of lignins. Using antisense technology to reduce expression of 4-coumarate:coenzyme A ligase, a key step in lignin biosynthesis, reductions of up to $45 \%$ in the lignin content and increases of up to $15 \%$ in the cellulose content have been obtained in aspen. Enhanced leaf, root, and stem growth were also observed (Hu et al. 1999; Sederoff 1999). Being able to reduce the lignin content of trees or to improve pulping properties has also been achieved by reducing cinnamyl alcohol dehydrogenase activity in 2-year-old poplar (P. tremula $\times$ P. alba) (Lapierre et al. 1999). This process could reduce the energy inputs required and pollutants released by the pulping industry. Further enhancements of vegetative growth and rate of biomass increase may become possible by manipulating ammonium metabolism in trees. Increased cellular glutamine synthetase activity can enhance synthesis of nitrogenous compounds and biomass growth (Suarez et al. 2002). The understanding of how wood is laid down under stress conditions is being enhanced by studies on xylem tension stress-responsive genes (Samuga and Joshi 2002)

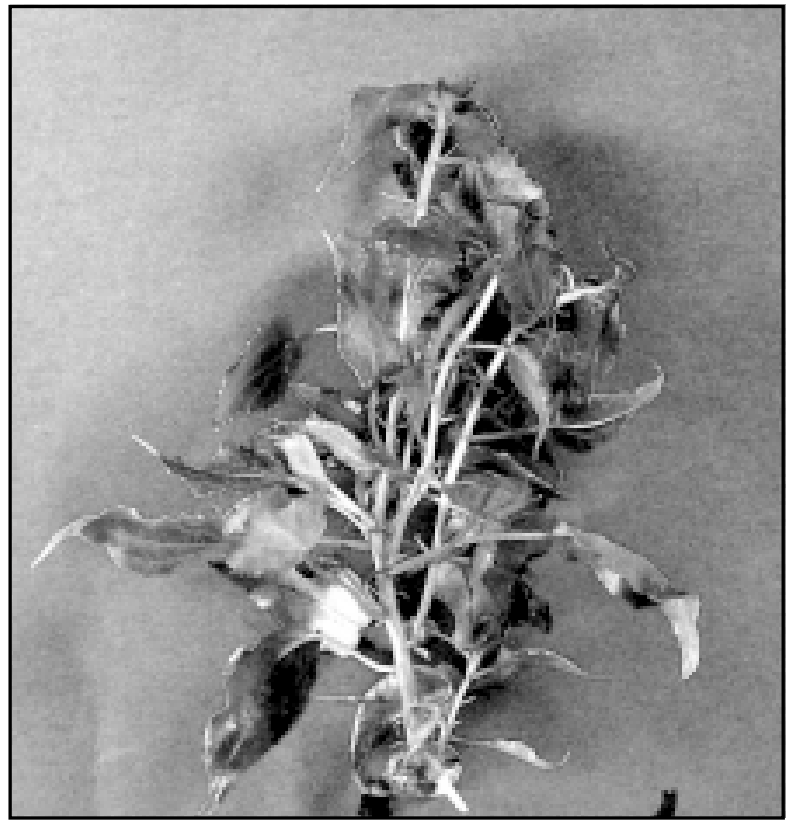

Figure 2. Genetically modified Populus species hybrid.

and the effects of rol $C$ gene expression in developing xylem in aspen (Grunwald et al. 2002).

Some of the time-related limitations of conventional tree breeding may be overcome by expressing thale cress (Arabidopsis thaliana) genes, such as apetela 1, or leafy in trees. Already, apetela 1 expression has shortened generation times from seed to seed from at least 5 years to a single year in the commercial citrus production rootstock citrange (Citrus sinensis $\times$ Poncirus trifoliata) (Pena et al. 2001). This result was achieved by converting apical and lateral shoots to flowers, and it is likely to have significant economic implications for the fruit tree industry. Similar results have been demonstrated in aspen, reducing flowering time to a mere 7 months (Nilsson and Weigel 1997; Martin-Trillo and Martinez-Zapater 2002).

Although greater understanding of flowering control is still required, the combination of genetic modification and DNA sequence information gained from analysis of earlyflowering mutants from Arabidopsis seems very likely to speed up future breeding programs considerably (Egea-Cortines and Weiss 2001). GM trees also have potential to produce valuable pharmaceuticals. Although at an early stage, rubber trees in Malaysia have been engineered to secrete human serum albumin. Other high-value commodities produced and easily harvested from GM trees, including vaccines in fruit, will no doubt become commercial realities in due course (Langridge 2000).

GM trees have significant potential for dendroremediationusing trees to clean up environmental pollutants. Restoring contaminated land sites reduces risks to the environment and 
greatly enhances the value of these sites. Considerable progress has been made with both heavy metals and with organic pollutants. Yellow poplar (Liriodendron tulipifera) modified to express bacterial mercuric reductase grows vigorously in normally toxic levels of ionic mercury, being able to convert the highly toxic ionic mercury (Hg [II]) to the much less toxic elemental form (Hg [0]) up to twelvefold faster than untransformed poplars (Rugh et al. 1998; Meagher 2000; Rugh 2001).

Using cultures of genetically modified poplar cells, Gordon et al. (1998) were able to degrade trichlorethylene, one of the world's major pollutants. Field study data have shown that up to $95 \%$ of available trichlorethylene was degraded to chlorine ions and $\mathrm{CO}_{2}$. Similar approaches are being followed with a range of other organic pollutants, including the explosives RDX and 2,4,6-trinitrotoluene (TNT) (Thompson et al. 1999). Using trees to clean up environmental pollutants, contaminated sites can be returned to useful service for housing, leisure, or light industry.

Arboricultural benefits from genetic modification are also likely to come from improved resistance to pests and diseases. Examples include introduced resistance to the fungal pathogen Septoria musiva in poplar expressing chitinbinding proteins Ac-AMP1.2 and ESF12 (Liang et al. 2002) and plum pox virus in Prunus domestica following expression of the viral coat protein (Ravelonandro et al. 1999). In Polish, Spanish, and Rumanian field tests, the GM plum trees allowed only low levels of viral multiplication from which the trees rapidly recovered. One such line was not infected at all over the 3-year duration of these trials, in contrast to the untransformed trees that all became infected during the first year (Ravelonandro et al. 2000). Resistance to the cottonwood leaf beetle (Chrysomela scripta), a major North American pest, may soon be possible among poplars following their genetic modification with Bt toxin genes (James et al. 1999). Similar trials are under way in China using the Cry 1 Ac gene in P. nigra to protect against the defoliators (Hu et al. 2001). Particular care is, however, likely to be needed when selecting appropriate $B t$ toxin strain genes due to regional differences in cottonwood leaf beetle susceptibility. Expression of the CTV viral p25 coat protein gene significantly increased viral resistance or delayed disease symptom onset in Mexican lime (Citrus aurantifolia) (Dominguez et al. 2002b), while commercialscale production of GM papaya resistant to ringspot virus is well established in Hawaii (Ferreira et al. 2002).

Genetic modifications can be used to restore trees to pest-damaged landscapes. Three potential examples are American chestnut (Castanea sativa), English elm (Ulmus procera), and some Southern pines (Pinus spp.) in the United States. More than 3 billion American chestnuts have been lost since the 1930s to Cryphonectria parasitica, the chestnut blight fungus. Genetic modification may prove beneficial in speeding up the breeding programs sponsored by the American Chestnut Foundation (Mehlenbacher et al. 2000). Hundreds of millions of elms throughout the northern hemisphere have been devastated by Dutch elm disease, a vascular wilt caused by the fungi Ophiostoma ulmi and O. novo-ulmi (Dunn 2000).

Within the United Kingdom alone, more than 20 million mature elms were lost in the 1970s, with fresh outbreaks still occurring as elm populations struggle to recover. However, biotechnology is making significant progress with English elm. Techniques for the transfer of genes into leaf and stem tissues using DNA-coated microprojectiles, and with both $A$. rhizogenes and A. tumefaciens, have been established. These techniques allow transgene expression to be investigated using biochemical reporter genes such as gus $A$ and gfp (Davey et al. 1998).

English elms with modified growth habit as a result of Ri plasmid gene expression and phenotypically normal English elms genetically modified with $\beta$-glucuronidase antifungal protein genes have been produced (Gartland et al. 2000, 2001a, 2001b) (Figure 3). Ulmus procera has some measure of in-built containment, as it does not form viable seed in UK conditions being propagated vegetatively. Elms in the United Kingdom, as well as in North America, hold great

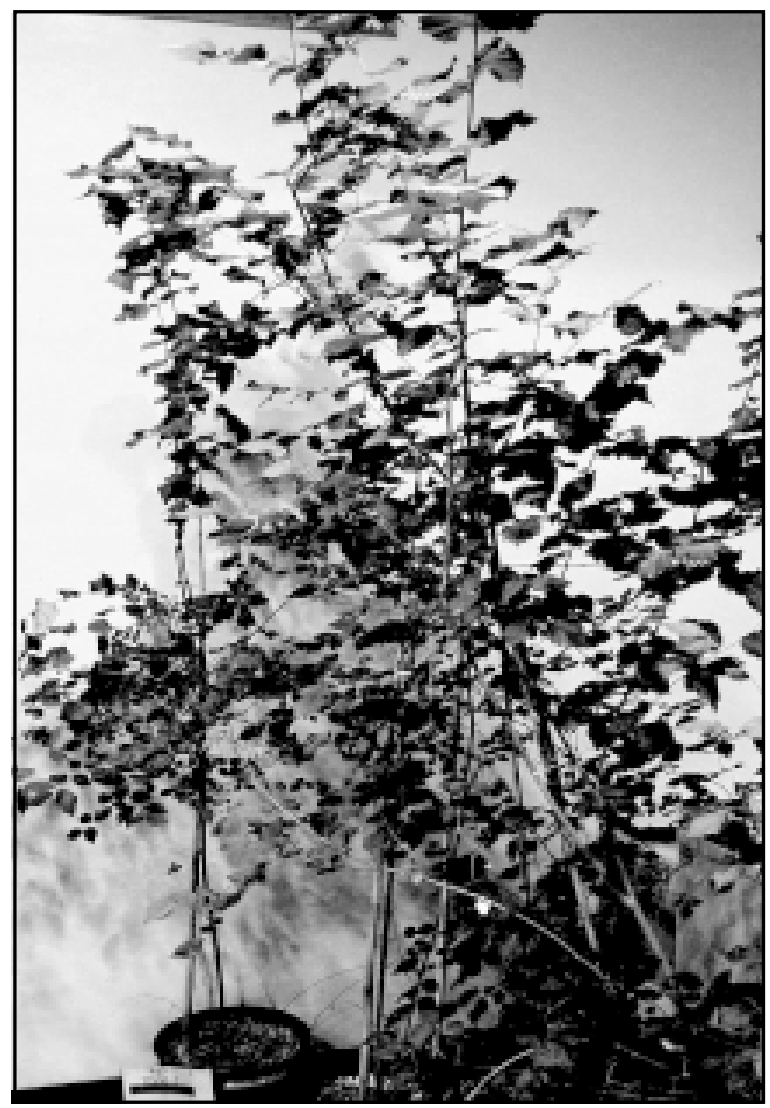

Figure 3. Genetically modified English elm (Ulmus procera) growing in soil. 
cultural, as well as landscape, amenity, and potential economic value.

White pine blister rust (Cronartium ribicola) has attacked pines in the United States (Pena and Seguin 2001). These trees, described by John Muir as the priests of pines addressing the surrounding forest, may benefit from a combination of genetic modification and genomics-the application of computer science to genetic structure and function. Gene mapping and genomic sequencing advances are likely to identify potential genes for resistance to white pine blister rust fungus. Such genes, once allied to suitable regulatory elements, could be transferred back into the pines by genetic modification, reducing future damage to the landscape.

\section{CONCLUSIONS}

Tree genetic modification is most likely to be acceptable to the public in two areas: where greater productivity from reduced plantation forest areas can be shown to increase areas left to nature's own devices, and in restoring threatened trees to damaged landscapes, such as the elm. Whichever aspects of GM trees advance most rapidly in the future, environmental risk assessment should always be carried out, on a case-by-case basis, until a sufficient body of knowledge on the anticipated benefits and the possible risks of this exciting technology is established.

\section{LITERATURE CITED}

Adams, J.M., G. Piovesan, S. Strauss, and S. Brown. 2002. The case for genetic engineering of native and landscape trees against introduced pests and diseases. Conserv. Biol. 16:874-879.

Allen, G.C., S. Spiker, and W.F. Thompson. 2000. Use of matrix attachment regions (MARs) to minimize transgene silencing. Plant Mol. Biol. 43:361-376.

Bouchie, A. 2001. Safety of GMOs reaffirmed by EU. Nat. Biotechnol 19:1095.

Dandekar, A.M., and D.J. James. 1998. High levels of expression of full-length cry IA(c) gene from Bacillus thuringiensis in transgenic somatic walnut embryos. Plant Sci. 131:181-193.

Daniell, H., and A. Dingra. 2002. Multigene engineering: Dawn of an exciting new era in biotechnology. Curr. Op. Biotechnol. 13:136-141.

Davey, M.R., K. C. Lowe, and J.B. Power (Eds.). 1998. Tree BiotechnologyTtowards the Millennium. Nottingham University Press, UK.

Dominguez, A., C. Fagoaga, L. Navarro, P. Moreno, and L. Pena. 2002a. Regeneration of transgenic citrus plants under non-selective conditions results in high-frequency recovery of plants with silenced transgenes. Mol. Genet. Genom. 267:544-556.
Dominguez, A., A.H. de Mendoza, J. Guerri, M. Cambra, L. Navarro, P. Moreno, and L. Pena. 2002b. Pathogenderived resistance to Citrus tristeza virus (CTV) in transgenic Mexican lime (Citrus aurantifolia (Christ.) Swing.) plants expressing its p25 coat protein gene. Mol. Breed. 10:1-10.

Dunn, C.P. (Ed.). 2000. The Elms_-Breeding, Conservation and Disease Management. Kluwer Academic Publishers, Boston, MA.

Ebinuma, H., K. Sugita, E. Matsunaga, and M. Yamakado. 1997. Selection of marker-free transgenic plants using the isopentenyl transferase gene. PNAS 94:2117-2121.

Egea-Cortines, M., and J. Weiss. 2001. A rapid coming of age in tree biotechnology. Nat. Biotechnol. 19:215-216.

Ellis, D.D., D.E. McCabe, S. McInnes, R. Ramachandram, D. R. Russell, K.M. Wallace, B.J. Martinell, D.R. Roberts, K.F. Raffa, and B.H. McCown. 1993. Stable transformation of Picea glauca by particle acceleration. Bio/Technol. 11:84-89.

Fenning, T.M., and K.M.A. Gartland. 1995. Transformation protocols for broadleaved trees. Meth. Mol. Biol. 44:149166.

Ferreira, S.A., K.Y. Pitz, R. Manshardt, F. Zee, M. Fitch, and D. Gonsalves. 2002. Virus coat protein transgenic papaya provides practical control of papaya ringspot virus in Hawaii. Plant Dis. 86:101-105.

Gartland, K.M.A., and M.R. Davey (Eds.). 1995. Agrobacterium Protocols. Methods in Molecular Biology 44. Humana Press.

Gartland, J.S. A.T. McHugh, C.M. Brasier, R.J. Irvine, T.M. Fenning, and K.M.A. Gartland. 2000. Regeneration of phenotypically normal English elm (Ulmus procera) plantlets following transformation with an Agrobacterium tumefaciens binary vector. Tree Physiol. 20:901-907.

Gartland, J.S., C.M. Brasier, T.M. Fenning, R. Birch, and K.M.A. Gartland. 2001a. Ri-plasmid mediated transformation and regeneration of Ulmus procera. Plant Growth Reg. 33:123-129.

Gartland, K.M.A., J.S. Gartland, and T.M. Fenning. 2001b. Improving elms. The Biochemist 23:21-23.

Gartland, K.M.A., T.M. Fenning, and R.B. Kellison. 2003. Forest biotechnology in Europe: Challenges, potential and opportunities, p 51072. In Proceedings, European Forest Biotechnology Forum. Institute for Forest Biotechnology, Research Triangle Park, NC.

Gordon, M.P., N. Choe, J. Duffy, G. Ekuan, P. Heilman, I. Muiznieks, M. Ruszaj, B.B. Shurtleff, S. Strand, J. Wilmoth, and L.A. Newman. 1998. Phytoremediation of trichlorethylene with hybrid poplars. Environ. Health Persp. 106:1001-1004.

Grunwald, C., K. Ruel, and U. Schmitt. 2002. Differentiation of xylem cells in rolC transgenic aspen trees-A study of secondary cell wall development. Ann. For. Sci. 59:679_ 685 . 
Hansen, G., and M.S. Wright. 1999. Recent advances in the transformation of plants. Trends Plant Sci. 4:1360-1385.

Hay, I., M.J. Morency, and A. Seguin. 2002. Assessing the persistence of DNA in decomposing leaves of genetically modified poplar trees. Can J. For. Res. 32:977-982.

Herschbach, C., and S. Kopriva. 2002. Transgenic trees as tools in tree and plant physiology. Trees Struct. Func. 16:250-261.

Hu, W.J., S.A. Harding, J. Lung, J.L. Popko, J. Ralph, D.D. Stokke, C.J. Tsai, and V.L. Chiang. 1999. Repression of lignin biosynthesis promotes cellulose accumulation and growth in transgenic trees. Nat. Biotechnol. 17:808-812.

Hu, J.J., Y.C. Tian, Y.F. Han, L. Li, and B.E. Zhang. 2001. Field evaluation of insect-resistant transgenic Populus nigra trees. Euphytica 121:123-127.

James, R.R., B.A. Croft, and S.H. Strauss. 1999. Susceptibility of the cottonwood leaf beetle to different strains and transgenic toxins of Bacillus thuringiensis. Environ. Entomol. 28:108-115.

Jefferson, R.A., T.A. Kavanagh, and M.W. Bevan. 1987. GUS fusions: Beta-glucuronidase as a sensitive and versatile gene fusion marker in higher plants. EMBO J. 6:3901-3907.

Kaneyoshi, J., and S. Kobayashi. 1999. Characteristics of transgenic trifoliate orange possessing the rol $C$ gene from Agrobacterium rhizogenes. J. Jpn. Hortic. Sci. 68:734-738.

Langridge, W.H. 2000. Edible vaccines. Sci. Am. 283:66-71.

Lapierre, C., B. Pollett, M. Petit-Conil, G. Toval, J. Romero, G. Pilate, J.C. Leple, W. Boerjan, V. Ferret, V. De Nadai, and L. Jouanin. 1999. Structural alterations of lignins in transgenic poplars with depressed cinnamyl alcohol dehydrogenase or caffeic acid O-methyl transferase activity have an opposite impact on the efficiency of industrial kraft pulping. Plant Physiol. 119:153-163.

Lev-Yadun, S., and R. Sederoff. 2001. Grafting for transgene containment. Nat. Biotechnol. 19:1104.

Liang, H.Y., C.M.Catranis, C.A. Maynard, and W.A. Powell. 2002 Enhanced resistance to the poplar fungal pathogen, Septoria musiva, in hybrid poplar clones transformed with genes encoding antimicrobial peptides. Biotechnol. Lett. 24:383-389.

Main, G.D., A. Williamson, R.J.Irvine, J.S. Gartland, T.M. Fenning, J. Mala, and K.M.A. Gartland. 1998. The use of gren fluorescent protein $(g f p)$ as a reporter gene in tree genetic manipulations, pp 315-320. In Davey, M.R., K.C. Lowe, and J.B. Power. (Eds.). Tree Biotechnology Towards the Millennium. Nottingham University Press, UK.

Martin-Trillo, M., and J.M. Martinez-Zapater. 2002. Growing up fast: Manipulating the generation time of trees. Curr. Op. Biotechnol.13:151-155.

Meagher, R.B. 2000. Phytoremediation of toxic elemental and organic pollutants. Curr. Op. Plant Biol. 3:153-162.

Mehlenbacher, S.A., R.L. Phillips, and H. van Buijtenen 2000. The TACF breeding program review. J. Am. Chestnut Foun. XIV:16-24.
Mouradov, A., and R.D. Teasdale. 1999. Genetic engineering of reproductive incompetence in radiata pine.

Protoplasma 208:13-17.

Nilsson, O., and D. Weigel. 1997. Modulating the timing of flowering. Curr. Op. Biotechnol. 8:195-199.

Ow, D. 2001. The right chemistry for marker gene removal? Nat. Biotechnol. 19:115-116.

Pena, L., and A. Seguin. 2001. Recent advances in the genetic transformation of trees. Trends Biotechnol. 19:500-06.

Pena, L., M. Martin-Trillo, J. Juarez, J.A. Pina, L. Navarro, and J.M. Martinez-Zapater. 2001. Constitutive expression of Arabidopsis LEAFY or APETELA1 genes in citrus reduces their generation time. Nat. Bioltechnol. 19:263-267.

Rautner, M. 2001. Designer trees. Biotechnol. Dev. Mon. 44:2-7.

Ravelonandro, M., R. Scorza, J.C.. Bachelier, G. Labonne, L. Levy, V. Damsteegt, A.M. Callahan, and J. Dunez. 1999. Resistance of transgenic Prunus domestica to plum pox virus infection. Plant Dis. 81:1231-1235.

Ravelonandro, M., R. Scorza, A. Calahan, L. Levy, C. Jacquet, M. Monsion, and V. Damsteegt. 2000. The use of transgenic fruit trees as a resistance strategy for virus epidemics: The plum pox (sharka) model. Virus Res. 71:63-69.

Richardson, D.M. 1998. Forestry trees as invasive aliens. Conserv. Biol. 12:18-26.

Rugh, C.L., J.F. Senecoff, R.B. Meagher, and S.A. Meikle. 1998. Development of transgenic yellow poplar for mercury phytoremediation. Nat. Biotechnol. 16:925-928.

Rugh, C.L. 2001. Mercury detoxification with transgenic plants and other biotechnological breakthroughs for phytoremediation. In Vitro Cell. Dev. Biol.-Plants 37:321-325.

Samuga, A., and C.P. Joshi. 2002. A new cellulose synthase gene (PtrCesA2) from aspen xylem is orthologous to Arabidopsis AtCesA7 (irx3) gene associated with secondary cell wall synthesis. Gene 296:37-44.

Sederoff, R. 1999. Building better trees with antisense. Nat. Biotechnol. 17:750-751.

Sears, M.K., R.L. Hellmich, D.E. Stanley-Horn, K.S. Oberhausser, J. M. Pleasants, H.R. Mattila, B.D. Siegfried, and G.P. Dively. 2001. Impact of Bt corn pollen on monarch butterfly populations: A risk assessment, pp. 11931-11937. In Proceedings of the National Academy Sciences 98.

Stewart, C.N. Jr., and S.K. Wheaton. 2001. GM crop dataAgronomy and ecology in tandem. Nat. Biotechnol. 19:3.

Strauss, S.H., W.H. Rottman, A.M. Brunner, and L.A. Sheppard. 1995. Genetic engineering of reproductive sterility in forest trees. Mol. Breed. 1:5-26.

Strauss, S.H., S.A. Knowe, and J. Jenkins. 1997. Benefits and risk of transgenic Roundup Ready cottonwoods. J. For. 95:12-19. 
Strauss, S.H., P. Coventry, M.M. Campbell, S.N. Pryor, and J. Burley. 2001. Certification of genetically modified forest plantations. Int. For. Rev. 3:87-104.

Suarez, M.F., C. Avila, F. Gallardo, F.R. Canton, A. GarciaGutierrez, M.G. Claros, and F.M. Canovas. 2002. Molecular and enzymatic analysis of ammonium assimilation in woody plants. J. Exp. Bot. 53:891-904.

Thompson, P.L., L.A. Ramer, and J.L. Schnoor. 1999. Hexahydro-1,3,5-trinitro-1,3,5-triazine translocation in poplar trees. Environ. Toxicol. Chem. 18:279-284.

Trick, H.N., and J.J. Finer. 1999. Induction of somatic embryogenesis and genetic transformation of Ohio buckeye (Aesculus glabra Willd.). In Vitro Cell. Dev. Biol.-Plant 35:57-60.

Tzfira, T., A. Vainstein, and A. Altman. 1999. rol-Gene expression in transgenic aspen (Populus tremula) plants results in accelerated growth and improved stem production index. Trees Struct. Func. 14:49-54.

Wenck, A.R., M. Quinn, R.W. Whetten, G. Pullman, and R. Sederoff 1999. High-efficiency Agrobacterium-mediated transformation of Norway spruce (Picea abies) and loblolly pine (Pinus taeda). Plant Mol. Biol. 39:407-416.

\footnotetext{
${ }^{1 *}$ Plant Biotechnology Research Group

School of Contemporary Sciences

University of Abertay Dundee

Dundee, DD1 1HG, Scotland

${ }^{2}$ Max Planck Institut für Chemische Oekologie

Jena, Germany
}

"Corresponding author.
Résume. La modification génétique au moyen du transfert de gènes via Agrobacterium peut permettre de surmonter les limitations quant à l'hybridation conventionnelle d'arbres. Des alternatives à l'utilisation de marqueurs sélectifs de résistance antibiotique et comment elles pourraient être utilisées pour surmonter les craintes potentielles du public sont décrites. Les applications de la modification génétique pour les arbres incluent l'altération des propriétés du bois, l'accroissement de la vitesse des cycles d'hybridation, l'emploi de la forêt comme manufacture pharmaceutique, la dendromédication, la résistance accrue aux insectes et aux maladies, tout comme la restauration de milieux sensibles.

Zusammenfassung. Die Grenzen von konventionellen Anzuchtmethoden bei Bäumen können durch genetische Modifikation unter Verwendung von Agrobacterium oder Gentransfer überwunden werden. Hier werden Alternativen zum Gebrauch von ausgewählten Markern in ihrer antibiotischer Resistenz und ihrer Anwendung bei möglichem öffentlichen Interesse beschrieben. Anwendungen genetischer Modifikationen an Bäumen schließen veränderte Waldbestände, Beschleunigung des Vermehrungszyklusses, Wälder als pharmazeutische Fabriken, Dendroremediation, verbesserte Resistenz gegenüber Krankheiten und Schädlingen und auch Restoration sensitiver Landschaften ein.

Resumen. La modificación genética utilizando Agrobacterium o transferencia genética biolística, puede traer limitaciones en la reproducción de árboles convencionales. Se discuten las alternativas de uso de marcadores de resistencia antibiótica y cómo pueden ser usados para vencer potenciales preocupaciones. La aplicación de modificaciones genéticas a los árboles abarca la alteración de las propiedades de la madera, el aceleramiento de los ciclos de reproducción, los bosques como fábricas farmacéuticas, la dendrorremediación, el mejoramiento de la resistencia a plagas y enfermedades, como también la restauración de paisajes de importancia. 